\title{
The Effect of The Strategy of The Memory Game on The Achievement of Chemistry Among the First Intermediate Grade Students
}

\section{${ }^{1}$ Assist Lecture Mohammed Mishal Raheem, ${ }^{2}$ Asst. Lecturer Khaled Hussein Hatam, ${ }^{3}$ Lecture. Mohammed Kamal Mohammed}

\author{
${ }^{1}$ Ministry of Education / Baghdad Directorate of Education AL-Karkh / Mohammedmishal 237@yahoo.com \\ ${ }^{2}$ Imam kadhum College (IKC) for Islamic Sciences, alkadhum-col.edu.iq \\ ${ }^{3}$ Ministry of Education / Baghdad Directorate of Education AL-Karkh / mmrrzzaa79@gmail.com
}

Article History: Received:11 January 2021; Accepted: 27 February 2021; Published online: 5 April 2021

\begin{abstract}
The present study aimed to know "the effect of the memory game strategy on the achievement of chemistry among first-grade intermediate students." To achieve this, the researchers chose the Al-Ma'moun Intermediate School for Boys affiliated to the Baghdad Education Directorate Al-Karkh / 1. ) Students for the experimental group and (33) students for the control group, and the researchers formulated (180) behavioral objectives within the levels of (remembering, comprehension, application, analysis) according to Bloom's classification of the cognitive domain, and the researchers prepared an achievement test consisting of (40) objective items Of the multiple choice type, and its psychometric properties were confirmed, and after processing the data statistically by using the T-test for two independent samples, the study reached the superiority of the experimental group who studied chemistry according to the memory game strategy in the achievement test of chemistry over the control group for those who studied on According to the usual method, and after interpreting the results, recommendations and proposals are drawn up.
\end{abstract}

Research problem:

Our current era is witnessing tremendous development in various fields of life, including the scientific, technical and educational fields. This has been accompanied by the development of the Iraqi curriculum as a basic step for the development of education in Iraq in line with the latest global developments in this field, and despite this development, most of the teaching methods used In the educational field, it does not lead to the achievement of educational goals effectively, as researchers have observed, through teaching chemistry for more than ten years, that most of the methods and methods commonly used in teaching them depend on lecturing and indoctrination by the teacher and memorization and memorization by the student, that is, they do not allow The student has an opportunity to learn the concepts properly, and it does not help him to remember clearly.

But the reality of the situation in our schools today is characterized by a general weakness in preparing and preparing the requirements for the success of the educational process for several reasons, and researchers have perceived this through their modest teaching experience and the views of many teachers, teachers and supervisors regarding low levels of understanding, thinking, remembering, information retention, and the possibility of its application in various situations.

This decline in the scientific level of students includes most of the scientific subjects, including the subject of chemistry, as researchers found that there is a weakness in the interest of some students to study this subject, because it includes various concepts and laws, which are difficult for students to understand, if presented in an abstract way, as They emphasized that the reason for students 'poor understanding of some scientific concepts may be due to the fact that some chemistry teachers still follow methods and methods that rely on memorization and indoctrination, and as a result leads to forgetting and atrophy of what students have learned after they employ their information without understanding it, or the interconnectedness between them., Which does not contribute to a functional function in their daily life.

This resulted in an important problem in the teaching and study of chemistry and in most academic levels, including intermediate ones, except that it is the wrong understanding of scientific concepts, and from this point of view, researchers have come to see a number of strategies to treat and diagnose this problem, and researchers have chosen (the strategy of the memory game) because it is one of the strategies that emphasize Recent trends in teaching them, 
as well as the scarcity of research conducted to test their effectiveness at the local and global level, according to the modest knowledge of researchers.

Therefore, the research problem lies in the following question:

"What is the effect of the strategy of the memory game on the achievement of chemistry among first-grade intermediate students?"

research importance :

The rapid scientific and technical development has led to wide changes in contemporary life patterns in all respects, causing the emergence of new problems that need to be solved for further development and progress. Perhaps the huge and rapid accumulation of scientific knowledge made this stage increase and multiply in short periods of time that had its repercussions. Accelerated education and education, specifically on the decisions, methods and methods of teaching science, as it is no longer within the limits of the usual patterns and methods of education and the abilities of the regular teacher to keep pace with the times and keep pace with it. (Olive, 1996: 86).

We can keep pace with what we aim at in terms of keeping pace with scientific progress unless we have a generation who believes in science, who possesses positive trends towards science and scientific progress and capacity development to face the challenges of the age, and rapid changes in society, and to achieve this, countries and their various institutions have adopted a tool to achieve what they aspire to. Goals, and education must accommodate all developments and changes as a result of the progress in knowledge and achieve its desired goals, which requires it to work to provide the student with information, concepts, theories and laws and to develop his skills, scientific trends and ways of thinking that make him able to understand his environment and be able to confront problems and solve them according to a sound scientific approach. (El-Sherbiny and Ferhati, 2004: 17).

Developments and changes require education to be a life necessity and a basic basis for the development of society, to prove its existence and its role in improving the intellectual output reached by man, as developed and even developing countries attach great hopes to educational systems in their belief that they are the decisive element of development events in all their dimensions, and increase the ability of the individual to Adapting to all the new scientific and technological variables, and this, in addition to cultural and psychological considerations, needs to develop creativity skills that qualify him to deal directly with sources of knowledge, and the prevailing teaching methods such as presentation, lecture, explanation, and presentation are one of the sources of difficulties in forming scientific concepts for students And acquiring it to some extent (Olive 1996: 84)

And given that the rapid change in all areas of life is the distinguishing feature of our world today, but the rates of the speed of this change almost shock many people, whether at the level of individuals or institutions, and as a result of this change it was necessary to respond to it by changing the functions of institutions of all kinds, patterns and sizes. And educational institutions in any society are more important than any other institutions to change, to keep pace with the nature of the times, and to respond to the transformations that sweep the various areas of life. (Mustafa, 1999: 9) More recently, attention has focused on preparing curricula content in general and chemistry in particular on the basis of scientific concepts, due to the possibility of avoiding deficiencies in the teaching of chemistry after it was based on the traditional approach in which the logical sequence of them is taken into account in order to be consistent, And the nature of the subject, and it develops some of the students' abilities and aptitudes, especially the mental ones, and also provides students with educational situations to acquire them, and through the outcome of knowledge they enable them to follow the new in the field of chemistry, and to reach conclusions and generalizations that make them more capable in facing their various life problems. (Al-Abbasi, 5: 2009)

In view of the importance of the intermediate stage in building the student's personality in its various aspects, and developing his abilities, especially the mental ones, in particular, because his learning is meaningful, based on sound understanding, which requires the use of models and strategies to correct the students 'misconceptions of concepts. (Happiness and Beauty, 1998: 6) 
A great interest has appeared since the end of the eighties to experiment with many non-traditional methods in the teaching and learning processes, and some of these methods have emerged from the constructivist theory from which many varied and useful teaching models are derived, and have great value in the teaching and learning processes. (Al-Mihi, 2003: 3-4)

In order for the curriculum content to be communicated well to students, it is necessary to follow an effective teaching method through which the steps of the education process are organized in order to reach the objectives of the lesson in the best scientific way possible, as the objectives of the lesson are not achieved, unless the teacher follows the appropriate method in communicating information and knowledge to His students are well and understandable (Abu Mughali and Abdel-Hafez, 2012: 235).

And all the previous constructive strategies and models do not depart from the fact that they are procedures that enable the student to carry out many scientific activities, and his active participation in them in order to deduce knowledge on his own, and for him to learn advanced levels that lead to the organization of his knowledge structure. (Zayer 2014: 425)

Many of those interested in active learning, from which the strategy of the memory game stems from, believe that failure to invest this learning in different educational situations may make the student not go beyond the remembering stage in learning, and thus his link to the course content and its various topics is often weak, as well as active learning is a challenge. For the teacher in terms of his ability to choose the appropriate activities in that type of learning and apply them at the right time.

Memory represents the first receptor for sensory input from the outside world, through which a large amount of information about the properties of the stimuli that interact with it is received via the various sensory receptors (visual, auditory, tactile, olfactory and appetitive) as it consists of a group of receptors, each of which is specific to a specific type of the information. (Eills etal, 1979: 129)

The visual sensory future is responsible for receiving visual experience, which is often in the form of the imagination of something, while the auditory sensory future means receiving the auditory experience in the form of echo, and memory plays an important role in accurately transmitting the image of the outside world, as what is stored in it are impressions And real pictures of external stimuli. (Coon, 1986: 340)

In light of these activities, active learning is not just a group or a series of different activities, but rather, it is a trend that is formed by both students and teachers, so that it makes learning effective, so the goal of this type of learning is to stimulate thinking among students so that they learn how to think with Increase their level of achievement.

The importance of the research can be summarized in the following points:

1- The current study seeks to test the strategy of the memory game as a new attempt in the teaching of chemistry, out of the framework adopted in the teaching of chemistry.

2- The memory game strategy can be used to teach and deliver the scientific material included in the first intermediate grade chemistry textbooks.

Research goal and hypothesis:

The current research aims to identify (the effect of the strategy of the memory game in the achievement of chemistry among first-grade students), by verifying the following null hypothesis:

"There is no statistically significant difference at the level of significance (0.05) between the average scores of the students of the experimental group who studied according to the strategy of the memory game, and the average scores of the students of the control group who studied in the usual way in the achievement test of chemistry."

search limits :

The limits of this research are limited to: 
1- First grade students are intermediate in Al-Ma'moun Intermediate School for Boys affiliated to the General Directorate of Education in Baghdad - Al-Karkh 1.

2- The science book for the first intermediate grade (chemistry part only) scheduled by the Ministry of Education General Directorate of Curricula for the academic year (2017-2018), second edition.

3- The first semester of the academic year (2019-2020).

Define terms:

Impact: He defined it (Shehata and Zainab, 2003) as:

"The outcome of a desirable or desirable change that occurs in the student as a result of the teaching process."

(Shehata and Zainab, 2003: 22)

The memory game: He defined it (Razuki and Soha, 2013) as:

"It is one of the active learning strategies that refer to the student's ability to retain the acquired knowledge, information, and ways of retrieving and knowing it." (Razuki and Soha, 2013: 56)

Achievement: He defined it (Allam, 2000) as:

"It is the degree of acquisition that the student attains or the level of success that he attains in a specific subject, educational or training field." (Alam, 2000: 305)

Theoretical framework:

Memory game:

The concept of the Gestalt theory on memory is hardly different from what Aristotle presented in this regard, in which he sees that the perceived sensory impression intersects with the stored memory effect. It stores the same neural mechanisms and considers that the process of recall or recall is a reactivation of a specific memory effect through the use of the same neural activity used in the initial perceptions of this effect (Hilgard \& Bower, 1981: 223)

Al-Zaghoul (2003) believes that the causes of forgetfulness are attributed to two factors:

1- Difficulty activating the effect during the remembering process.

2- The decay of the effect due to interference with other memory effects.

Specifically, the Gestalt theory emphasizes the dynamic nature of memory, as it considers that the perceptual system is active and effective and works permanently to reorganize the components of memory in the light of developments resulting from the action of continuous and repeated interactions with environmental sensory goodies. It is reorganized or combined with other effects, or it may overlap with others, and as a result, there may be difficulty in the process of remembering them. (Zaghoul 2003: 168)

Steps to implement the strategy of the memory game:

1- Students form groups of (3-4) students for each group.

2- The teacher writes on a large piece of paper a set of facts ranging between (8-10) about a specific scientific concept or phenomenon, provided that he provides three copies of what he wrote, and he hangs the three copies in front of the students (at the front of the class)

3- An individual from each group begins to come forward and see what was written in the paper for a period of (30) seconds only, so if the number of students in the group is four, then the group has four opportunities to see what was written in the paper, and the time allotted for viewing the written depends The level and complexity of written things. 
4- Students in each group must write exactly what was written on the paper hanging in the front in their papers without any decrease or addition, for example if there are pictures, drawings or using colors, students must do that also and use the same colors.

5- After the first student from the group finishes seeing what was written on the hanging paper, summarizing what he saw, then the second student goes and so on, and here the students must cooperate in finding an appropriate way to remember everything written in the hanging paper in front.

6- Students compare what they wrote and put in their papers with what is on the original paper.

7- The teacher discusses with his students the methods they used to transfer what is on the original paper hanging in front of them to their groups.

(Ambu Saidi and Hoda, 2016: 82)

\section{Collection:}

The need or motivation for achievement achievement that is based on the student's effort and competition in order to reach high levels of performance, this individual achievement must be determined by the extent of students 'ability to control, analyze, organize, and properly process information for the purpose of achieving educational and educational goals. The final outcome is in terms of the difference in individual differences among students in the student's embarkation process or size, or in terms of success or fear of failure, and that the final outcome of success depends on the student's motivation, and the good investment of his potential, personal and educational abilities that lead him to achievement achievement. The variation of the motives for success among students is affected by many factors that have a link or effect on the academic achievement of individuals, including intelligence, motivation and mental abilities, and the motives for avoiding failure rise in the sense that the motives for success and the motives for avoiding failure must be related to achievement and excellence in it. (Al-Zayat, 2001: 336)

Those concerned with education pay great attention to achievement due to its importance in the life of the individual and the consequent educational decisions that result from it. Achievement tests are an organized method aimed at measuring the amount of information that the student saves or remembers in any field of knowledge, as well as his ability to understand or apply it, And analyzing it, and using it in various life situations, so educational institutions are interested in achievement, because it is an indication of the extent of progress towards educational goals. On the efficiency of institutions and their ability to achieve their goals, where achievement determines to a considerable degree the social and economic value of the individual, as it is a sign of his social values and career ambition that the individual aspires to achieve (Al-Zahir et al. 1999: 50).

There are aspects of achievement that the school should develop, and they are:

1. The ability to remember and use facts: It is concerned with the type of achievement that the achievement tests seek to measure among students.

2. Practical skills: It is concerned with the ability to apply knowledge with a focus on problem-solving and research skills.

3. Personal and social skills: It is concerned with the student's ability to communicate and communicate with others, and personal facts such as initiative, self-reliance, leadership readiness, and others.

4. Motivation and self-confidence: concerned with the student's perception of himself and his abilities.

(Malik et al., 1999: 25)

There are a number of factors affecting the collection process, which he referred to (Al-Essawi, 2000), including:

1. The extent to which students have self-motivation (internal), interest in studying, and exerting effort and energy in it.

2. The amount of physical, mental and psychological integrity that the student enjoys. 
3. Teaching methods and the accompanying excitement, suspense, and attract students' attention, and involve the student in educational activity, reinforcement, and so on, and this is a kind of external motivation for learning.

(Al-Essawi, 2000: 149).

Previous studies:

There are no previous local or international studies dealing with the memory game strategy, according to the researchers' knowledge.

Choose an experimental design

The researchers adopted the design of partial control with a post-test for two equivalent groups (experimental and control) as in the following scheme:

\begin{tabular}{||l|r|r|l||}
\hline $\begin{array}{c}\text { Dependent } \\
\text { variable }\end{array}$ & Independent variable & Parity & the group \\
\hline & strategy & & \\
& Memory game & Chronological age calculated in months & Experimental \\
Achievement test & -IQ test & Crevious information \\
\cline { 2 - 4 } & The usual way & Science grades & Control \\
\cline { 2 - 4 } & & & \\
\end{tabular}

Determine the research community, and choose its sample:

research community:

The research community consists of intermediate first-grade students of the Baghdad Education Directorate / AlKarkh 1, for the academic year (2019-2020).

The research sample:

Coordination was made with the administration of (Al-Ma'moun Intermediate School for Boys) for boys, as the school includes (175) students in the first intermediate grade distributed among (4) classes, and in a random manner, Division (B) was chosen to be the experimental group that studies in (Memory Game Strategy) and Division (D) To be the control group that studies in the (the usual way) and thus the sample reached (64) students.

Equivalence of the two research groups:

Although all the members of the research sample are in one geographical area and from a somewhat similar socioeconomic milieu and their distribution among the people was random by the school administration, but the researchers decided to do the equivalence of groups with the following variables, as shown in the following table: 
${ }^{1}$ Assist Lecture Mohammed Mishal Raheem, ${ }^{2}$ Asst. Lecturer Khaled Hussein Hatam, ${ }^{3}$ Lecture. Mohammed Kamal Mohammed

\begin{tabular}{|c|c|c|c|c|c|c|c|c|}
\hline \multirow{2}{*}{$\begin{array}{c}\text { Statistical } \\
\text { significance }\end{array}$} & \multicolumn{2}{|c|}{ Value $t$} & \multirow{2}{*}{$\begin{array}{l}\text { Degree } \\
\text { of free }\end{array}$} & \multirow{2}{*}{ variance } & \multirow{2}{*}{ SMA } & \multirow{2}{*}{ No. } & \multirow{2}{*}{ group } & \multirow{2}{*}{ Variables } \\
\hline & Tabular & $\begin{array}{c}\text { Calculate } \\
\text { d }\end{array}$ & & & & & & \\
\hline \multirow[t]{2}{*}{ Not sign } & \multirow{2}{*}{2} & \multirow{2}{*}{0.172} & 62 & 4.81 & 153.86 & 31 & $\begin{array}{c}\text { Experime } \\
\text { ntal }\end{array}$ & \multirow[t]{2}{*}{$\begin{array}{c}\text { Chronological } \\
\text { age }\end{array}$} \\
\hline & & & 62 & 9.09 & 153.41 & 33 & Control & \\
\hline \multirow{2}{*}{ Not sign } & \multirow{2}{*}{2} & \multirow{2}{*}{0.258} & 62 & 1.75 & 10.75 & 31 & $\begin{array}{c}\text { Experime } \\
\text { ntal }\end{array}$ & \multirow{2}{*}{$\begin{array}{l}\text { Previous } \\
\text { information }\end{array}$} \\
\hline & & & 62 & 1.74 & 10.91 & 33 & Control & \\
\hline \multirow{2}{*}{ Not sign } & \multirow{2}{*}{2} & \multirow{2}{*}{0.710} & 62 & 5.24 & 15.4 & 31 & $\begin{array}{c}\text { Experime } \\
\text { ntal }\end{array}$ & \multirow[t]{2}{*}{ Intelligence } \\
\hline & & & 62 & 3.13 & 16.6 & 33 & Control & \\
\hline \multirow{2}{*}{ Not sign } & \multirow{2}{*}{2} & \multirow{2}{*}{1.787} & 62 & 4.48 & 64.31 & 31 & $\begin{array}{c}\text { Experime } \\
\text { ntal }\end{array}$ & \multirow{2}{*}{$\begin{array}{c}\text { Science subject } \\
\text { degrees }\end{array}$} \\
\hline & & & 62 & 3.98 & 72.36 & 33 & Control & \\
\hline
\end{tabular}

Search Supplies:

After the researchers reviewed the science book for the first intermediate grade (the section devoted to chemistry), its contents and its analysis, the researchers formulated (180) behavioral objectives based on Bloom's classification in the cognitive domain for all levels, namely:

- Remembrance (knowledge).

- Comprehension.

- The application application.

Analysis.

Thus, the agreed behavioral objectives are distributed in the following table according to the seasons:

\begin{tabular}{|c|c|c|c|c|c|c|c|c||}
\hline \multicolumn{4}{|c|}{ The percentage of levels of behavioral targets } & \multicolumn{3}{c|}{ Academic content } & The \\
\hline $\begin{array}{c}\text { total } \\
\% 100\end{array}$ & $\begin{array}{c}\text { Analyzing } \\
\% 3\end{array}$ & $\begin{array}{c}\text { Implementation } \\
\mathbf{\%} 4\end{array}$ & $\begin{array}{c}\text { Accommodating } \\
\mathbf{\% 4 4}\end{array}$ & $\begin{array}{c}\text { Remember } \\
\mathbf{\% 4 9}\end{array}$ & Importance & $\begin{array}{c}\text { Number } \\
\text { of } \\
\text { shares }\end{array}$ & $\begin{array}{c}\text { Chapter } \\
\text { title }\end{array}$ & Chapter \\
\hline 10 & 0 & 0 & 5 & 5 & 26 & 5 & $\begin{array}{c}\text { Material } \\
\text { properties }\end{array}$ & the first \\
\hline
\end{tabular}


The Effect Of The Strategy Of The Memory Game On The Achievement Of Chemistry Among The First Intermediate Grade Students

\begin{tabular}{|c|c|c|c|c|c|c|c|c|}
\hline 17 & 1 & 1 & 7 & 8 & 42 & 8 & $\begin{array}{c}\text { Atoms, } \\
\text { Elements, } \\
\text { and } \\
\text { Compounds }\end{array}$ & $\begin{array}{l}\text { The } \\
\text { second }\end{array}$ \\
\hline 13 & 0 & 1 & 6 & 6 & 32 & 6 & $\begin{array}{c}\text { The } \\
\text { composition } \\
\text { and } \\
\text { varieties of } \\
\text { elements }\end{array}$ & the third \\
\hline 40 & 1 & 2 & 18 & 19 & $\% 100$ & 19 & \multicolumn{2}{|c|}{ total } \\
\hline
\end{tabular}

In addition to the numbers (30) plans for the experimental group, and the same for the control group, as for the test map, it is as follows:

Distribution of behavioral goals between levels and between the academic content

\begin{tabular}{|c|c|c|c|c|c|c||}
\hline \multirow{2}{*}{ total } & \multicolumn{4}{|c|}{ Cognitive domain } & Academic levels & The \\
\cline { 2 - 6 } & Analyzing & Implementation & Accommodating & Remember & Content \\
\hline $\mathbf{4 7}$ & 2 & 5 & 18 & 22 & Material properties & the first \\
\hline $\mathbf{8 8}$ & 2 & 1 & 43 & 42 & $\begin{array}{c}\text { Atoms, Elements, and } \\
\text { Compounds }\end{array}$ & $\begin{array}{c}\text { The } \\
\text { second }\end{array}$ \\
\hline $\mathbf{4 5}$ & 3 & 2 & 18 & 22 & $\begin{array}{c}\text { The composition and } \\
\text { varieties of elements }\end{array}$ & the third \\
\hline $\mathbf{1 8 0}$ & $\mathbf{7}$ & $\mathbf{8}$ & $\mathbf{7 9}$ & $\mathbf{8 6}$ & \multicolumn{2}{c||}{ total } \\
\hline
\end{tabular}

Search tool:

The researchers prepared an achievement test consisting of (40) items, and the test items were determined of the multiple-choice type, and its apparent validity was extracted based on the Cooper equation, which showed $80 \%$ of the opinions of arbitrators in education and methods of teaching chemistry, and with a preliminary application of the exploratory experiment For the achievement test, in order to determine the ambiguities and determine the time required for the test and it was (50) minutes, as for the second exploratory experiment which was conducted to conduct the statistical analysis of the test items by extracting the difficulty factor, which is $(0.38-0.73)$ and is considered good and acceptable, as for the strength of the distinction, it was $(0,21-0,70)$ is good, acceptable and within the specified range, as well as the effectiveness of the wrong alternatives was detected, and the results were of a negative value, as the values ranged between $(0.03-0.27)$, so the alternatives are effective, and the reliability of the test was also extracted Using the method (Kyoder-Richardson 20), where it reached (0.78) and thus it is a good reliability coefficient.

Statistical means: 
The T-Test was adopted for two independent samples (T-Test), (for the purpose of knowing the equivalence of the two groups in the variables), the equation of the difficulty coefficient for the objective items, the strength of discrimination equation, the equation for the effectiveness of alternatives (for the purpose of knowing the psychometric properties of the research tool), Cooper's equation, variance, and equation ( Kyoder Richardson - 20), as a statistical means of processing the research results.

Presentation and interpretation of results:

This chapter includes a presentation of the findings of the research, according to the aim of the research and its hypotheses, and then discussion and interpretation of them in light of the treatments, then stating the conclusions, recommendations and proposals as follows:

First: Presentation of results:

For the purpose of verifying the null hypothesis which states that:

"There is no statistically significant difference at the level of significance (0.05) between the average grades of students who study using the memory game strategy and the average grades of students who study in the usual way in the academic achievement of chemistry.

The arithmetic mean of the experimental group of (30.31) and the variance (3.17) were extracted. As for the control group, the arithmetic mean was (24.14) and the variance (3.26). The calculated T value (2.371) is greater than the tabular value (2), and the following table explains that.

\begin{tabular}{|c|c|c|c|c|c|c|c|}
\hline $\begin{array}{c}\text { Statistical } \\
\text { significance at the } \\
\text { level of significance } \\
\mathbf{0 . 0 5}\end{array}$ & t tabular & T calculate & $\begin{array}{c}\text { Degree } \\
\text { of free }\end{array}$ & variance & SMA & No. & group \\
\hline sign & 2 & 2.371 & 62 & 3.17 & 30.31 & 31 & $\begin{array}{c}\text { Experimenta } \\
1\end{array}$ \\
& & & & 3.26 & 24.14 & 33 & Control \\
\hline
\end{tabular}

This indicates that the difference between the mean differences is statistically significant for the benefit of the experimental group that studied the memory game strategy, and thus rejects the null hypothesis.

Second: Interpretation of the results:

The current study believes that the superiority of the experimental group over the control group students in the achievement test is due to the following:

1- The strategy of the memory game has led to an increase in motivation towards learning, as this strategy increases students 'desire to search for facts and investigate pending information through increased thinking, linking relationships between them, and the multiplication of questions and inquiries.

2- The strategy of the memory game includes various activities that help to assimilate and apply information effectively, emphasize the interaction between students in the educational process, and facilitate the effect of learning transmission. 
3- Teaching according to the strategy of the memory game helped to control time and lesson, and teachers can apply it in our Iraqi schools within the available capabilities.

Third: Conclusions:

In light of the results of the current research, the following can be concluded:

The use of the memory game strategy in teaching chemistry has a positive effect on raising the level of achievement among first-intermediate grade students.

Fourth: Recommendations:

In light of the findings of the research, the current study recommends the following:

1- Adopting chemistry teachers as a strategy for the memory game in teaching chemistry in general, and teaching other sciences as well because of their positive impact on increasing achievement.

2- Developing school curricula and updating them at the elementary, intermediate and preparatory levels, in order to develop the skills of love for educational games that stimulate memory.

3- Students in the elementary, middle and middle school levels really need a strategy for the memory game, and make them think instead of memorizing the cue.

Fifth: Proposals:

To complete this research, the researchers suggest conducting the following studies:

1 - The effect of the strategy of the memory game on science achievement among fifth grade primary students.

2- The effect of the strategy of the memory game in correcting the misconception of second grade intermediate students in the subject of chemistry.

3- Conducting a study similar to the current study in revealing the effect of the memory game strategy on variables other than those adopted in the current study, such as attitudes, motivation, acquisition of concepts, critical thinking, ability to solve problems, and scientific curiosity, ... etc.

Sources:

- Abu Mughali, Sami 'and Abdel-Hafiz Salameh (2012), Introduction to Education, 2nd Edition, Al-Yazouri House for Publishing and Distribution, Amman.

- Ambu Saeedi, Abdullah bin Khamis and Hoda Bint Ali Al-Huwaisna (2016): Strategies for Active Learning 180 Strategies with Applied Examples, 2nd Edition, Dar Al Masirah, Amman.

- Razooqi, Raad Mahdi and Soha Ibrahim Abdul Karim (2013): Thinking and its Types (Patterns), Part Two, College Library for Printing, Baghdad.

- Zayer, Saad Ali and others (2014): The Contemporary Educational Encyclopedia, 1st Edition, Part Two, Nour AlHassan Office, Baghdad.

- Al-Zaghoul, Imad (2003): Theories of Learning, First Edition, Dar Al-Shorouk for Publishing and Distribution, Amman.

- Al-Zayat, Fathy Mostafa (2001): Cognitive Psychology, Part One, Studies and Research, 1st Edition, University Press, Egypt.

-Zaitoun, Ayesh Mahmoud (1996): Methods of Teaching Science, 2nd Edition, Dar Al Shorouk, Amman. 
${ }^{1}$ Assist Lecture Mohammed Mishal Raheem, ${ }^{2}$ Asst. Lecturer Khaled Hussein Hatam, ${ }^{3}$ Lecture. Mohammed Kamal Mohammed

- HE, Jawdat Ahmed and Gamal Yaqoub Youssef (1988): Teaching the concepts of Arabic language, mathematics, science and social education, 1st Edition, Dar Al Jabal, Beirut.

- Shehata, Hassan and Zainab Al-Najjar (2003): Dictionary of Educational and Psychological Terms, 1st Edition, Arab Lebanese House, Cairo.

- El-Sherbiny, Hanim and Al-Farhati Al-Farhati (2004): The relationship of metacognitive skills to achievement goals and the method of attributing failure among university students, Studies in University Education, Issue Seven, Egypt.

- Al-Zahir, Zakaria Muhammad, Jacqueline Tamerjian, and Judat Ezzat Abdel-Hadi, (1999): Principles of Measurement and Evaluation in Education, House of Culture, Amman

- Al-Abbasi, Munther Mubader Abdul-Karim (2009): "Instructional-learning design according to Landa's theory and its effect on conceptual acquisition, problem solving and creative thinking among fourth-grade general students" (unpublished PhD thesis), University of Baghdad - College of Education - Ibn al-Haytham.

- Allam, Salah El-Din Mahmoud (2000): Educational and psychological measurement and evaluation (its basics, applications, and contemporary directions), 1st Edition, Arab Thought House, Cairo.

- Al-Essawi, Abd al-Rahman Muhammad (2000): The Path to Scientific Excellence, Encyclopedia of Modern Psychology Books, University Ratib House, Beirut.

- Malek Gilksart and others (1999): The Smart School, translated by Kamal Dawani, Jordan Book Center, Amman.

- Mustafa, Abd Al-Sami Muhammad (1999): Learning Technology, Arabic Studies, 1st Edition, Al-Kitab Center for Publishing, Cairo.

- Al-Mihi, Rajab Al-Sayed (2003): "The effect of the difference in the pattern of practicing educational activities in a proposed teaching model based on technological innovations and constructivist theory on the achievement and development of image-reading skills and innovative thinking in science among high school students with an internal and external control center," Journal of Scientific Education The Egyptian Society for Scientific Education, Volume 6, Issue 3, Faculty of Education, Ain Shams University, Cairo.

Foreign sources:

- Coon,D(1986).Introduction to psychology: Exploration and application, $\left(4^{\text {th }}\right.$ ed).west publishing Co

- Ellis.H.C Bennett, T.L, Daniel, T.c\& Rickert, E.J(1979). Psychology of learning and memory , Wadsworth publishing company.Inc

- Hilgard ,E,r,\&Bower,G,H.(1981): Theories of learing .(5 th ed) Prentice- Hall,Inc. 